Feasibility and Cost of Using a Computer to Prepare Landslide Susceptibility Maps of the San Francisco Bay Region, California

G E O L O G I C A L S S U R V E Y B U L L E T I N 1443

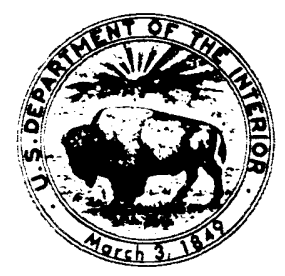

$00750 \mathrm{xON}$

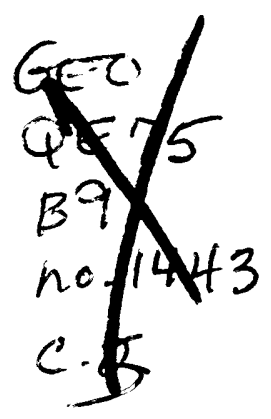





\section{Feasibility and Cost of Using a Computer to Prepare Landslide Susceptibility Maps of the San Francisco Bay Region, California}

By EVELYN B. NEWMAN, ARTHUR R. PARADIS, and EARL E. BRABB

GE OLOG ICAL S URVEY B ULLET I N 1443 


\section{UNITED STATES DEPARTMENT OF THE INTERIOR}

CECIL D. ANDRUS, Secretary

GEOLOGICAL SURVEY

W.A. Radlinski, Acting Director

Library of Congress Cataloging in Publication Data

Newman, Evelyn B.

Feasibility and cost of using a computer to prepare landslide susceptibility maps of the San Francisco Bay Region, California.

(Geological Survey Bulletin 1443)

Bibliography: p. 10

Supt. of Docs. no.: I 19.3:1443

1. Landslides-Maps-Computer programs. 2. Landslides-Maps--Costs. 3. LandslidesCalifornia-San Francisco Bay region-Maps. I. Paradis, Arthur R., joint author. II. Brabb, Earl E., 1929- joint author. III. Title: Feasibility and cost of using a computer to prepare landslide susceptibility maps... IV. Series: United States. Geological Survey. Bulletin 1443.
QE75.B9 no. 1443
[QE599.A2]
557.3 '08s [551.3'5'3]
$77-608264$

\footnotetext{
For sale by the Superintendent of Documents, U. S. Government Printing Office Washington, D. C. 20402
}

Stock Number 024-001-03067-5 


\section{CONTENTS}

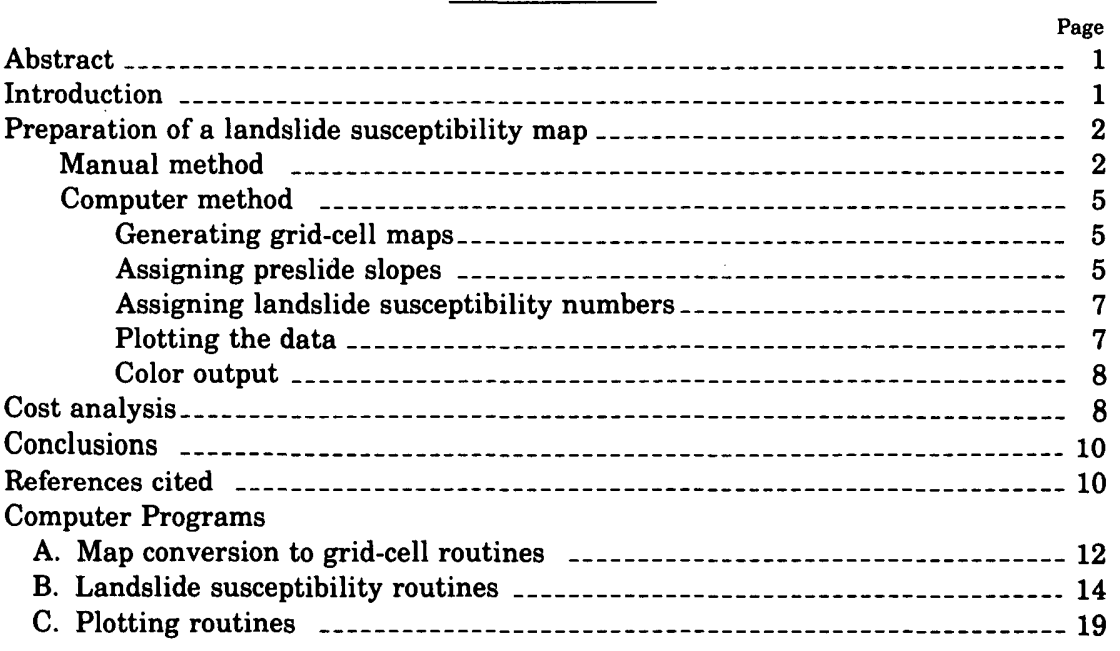

\section{ILLUSTRATIONS}

Plate 1. Comparison of manual and computer generated maps of test area in San Mateo County, Calif. ............. In pocket

Figure 1. Index map showing landslides in San Mateo County, Calif., and location of test area

2. Diagrams showing conversion of map units to grid-cell format ...... 6

3. Labeled geologic map of test area drawn by plotter _........... 9

\section{TABLES}

TABLE 1. Landslide susceptibility class number for rock units in test area in San

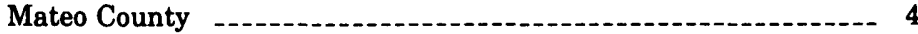

2. Time and cost of producing computerized map 


$$
\text { . }
$$




\section{FEASABILITY AND COST OF USING A COMPUTER TO PREPARE LANDSLIDE SUSCEPTIBILITY MAPS OF THE SAN FRANCISCO BAY REGION, CALIFORNIA}

By Evelyn B. Newman, Arthur R. Paradis, and Earl E. Brabb

\section{ABSTRACT}

Geologic, landslide, and slope maps of an area near San Francisco were digitized and converted to grid cell form for easy manipulation by computer. Landslide susceptibility categories were assigned to grid cells on the basis of the percentage of the rock units that had failed by landsliding in each slope category. The resulting landslide susceptibility map units were assigned color codes by computer, and color film was exposed by an image recorder. A comparison of the manual and computer-generated versions of the area shows the feasibility of compiling landslide susceptibility maps by computer in approximately the same time and at less cost than the manual version, with the benefits of less human labor and error and the availability of grid cell data for future mapping.

\section{INTRODUCTION}

Landslides were at least a $\$ 25,000,000$ problem in the San Francisco Bay region during the rainy season of 1968-69 (Taylor and Brabb, 1972). The U.S. Geological Survey, in cooperation with the U.S. Department of Housing and Urban Development, is studying these landslides and other geologic problems as part of a pilot project to test the usefulness of environmental resource data in improving urban planning and decisionmaking. One of the early products of this project is a landslide susceptibility map of San Mateo County at 1:62,500 scale (Brabb and others, 1972). The map provides an easily read analysis of selected geologic factors related to landsliding in the county. Unfortunately, the cost and difficulty of preparing the map were greater than expected; therefore, simpler, less expensive, and smaller scale $(1: 125,000)$ maps are being prepared for the rest of the nine-county bay region.

The need for large-scale (1:62,500 and larger) landslide susceptibility maps has been firmly established in the San Francisco Bay region. The San Mateo County map has been used by the county to establish the density of development, to require geologic investigations before development is approved, and to prepare seismic safety, open-space, 
and conservation elements of the county general plan. A similar map at $1: 24,000$ scale is being prepared for the city of San Jose. Several other counties and cities have expressed the desire for these maps if the cost is reasonable, which generally means a few tens of thousands of dollars.

There is, in addition to the need for landslide susceptibility maps, a need for more understanding of the relative importance of all the factors related to the landslide process. Brabb, Pampeyan, and Bonilla (1972) selected the areal extent of landsliding in each geologic unit and the original slope as the most critical factors in San Mateo County, but other factors such as the orientation of bedding relative to the slope, nearness to faults, rainfall, and vegetation should also be investigated. They were not investigated for the San Mateo County map because no simple correlations could be established by visual inspection, and because of the great difficulty in analyzing several subtle factors simultaneously in a large area.

The purpose of this study was to determine if computer techniques could be used to make a landslide susceptibility map of a selected test area of approximately 15 square miles in San Mateo County at a reasonable cost, and to estimate the cost of preparing similar maps for representative counties in the San Francisco Bay region. The location of the test area is shown on figure 1. The investigation will be used to establish the methodology and eventually the cost for more sophisticated regional analyses of several factors related to the formation of landslides.

Evelyn Newman wrote most of the report and selected the computer methods used in the analysis. Arthur Paradis converted map information into numerical form (digitized) and wrote most of the computer programs. Earl Brabb wrote part of the report and was responsible for determining the scope and objectives of the investigation.

\section{PREPARATION OF A LANDSLIDE SUSCEPTIBILITY MAP MANUAL METHOD}

The original landslide susceptibility map of San Mateo County (Brabb and others, 1972) was prepared from an analysis of a geologic map (Brabb and Pampeyan, 1972a), a landslide map (Brabb and Pampeyan, 1972b), and an experimental slope map, all at 1:62,500 scale. The maps were originally used in the following manner:

1. The area of outcrop within San Mateo County. was determined for each of the geologic formations (rock units) and some subunits on the geologic map using a grid overlay with a resolution of $0.01 \mathrm{mi}^{2}$ $\left(6.4\right.$ acres or $\left.0.0259 \mathrm{~km}^{2}\right)$ at the map scale.

2. The landslide inventory map was superimposed on the geologic 


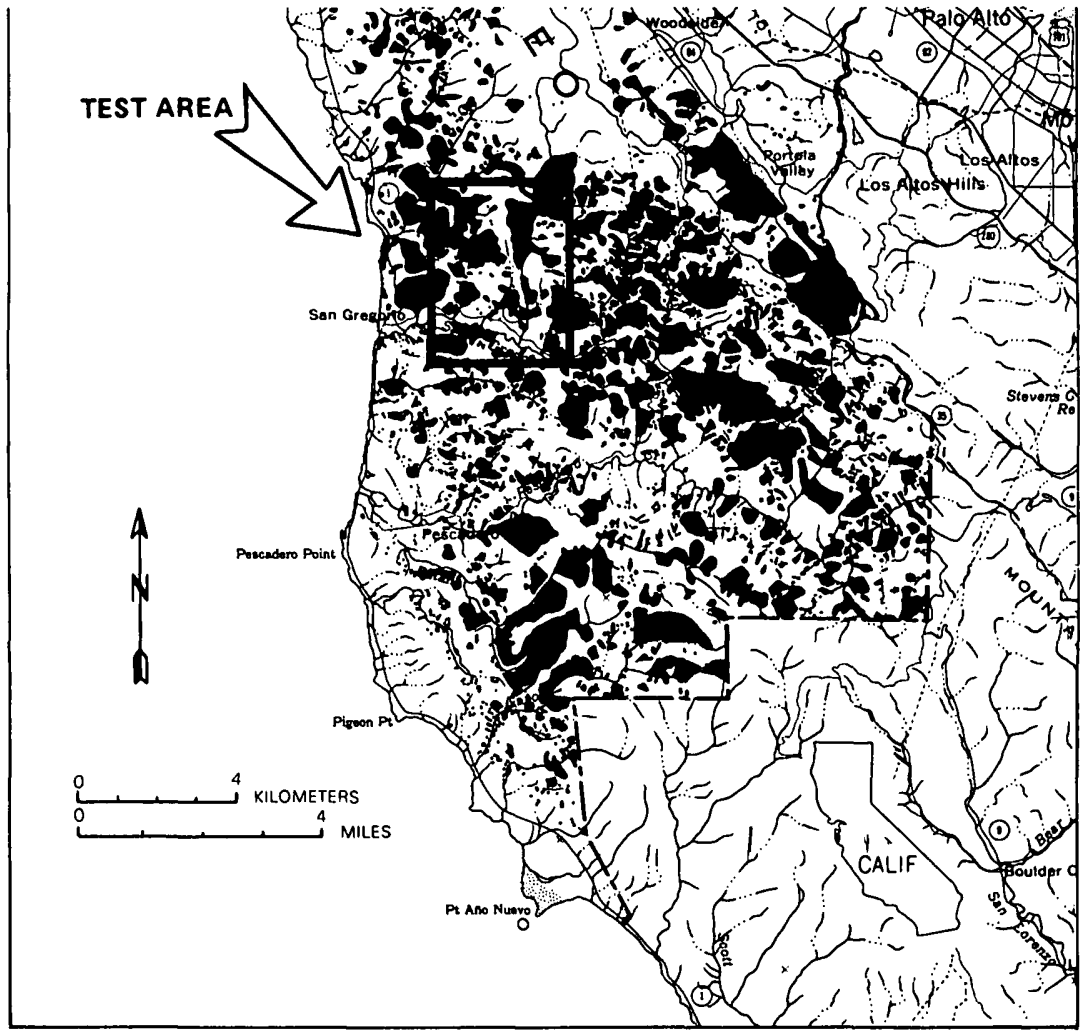

Figure 1.-Index map showing landslides in San Mateo County, Calif., and location of test area.

map in order to identify the rock units in which slope failures had occurred. The areas that had failed in each unit were measured using the grid.

3. The rock units were then listed in order of percentage of their outcrop areas that have failed by landsliding (see table 1).

4. The highest class of susceptibility (7) was assigned to the landslide deposits.

5. Other class limits were established at selected intervals on the list, and a class number from 1 to 6 was assigned to the map units. That number represents the relative susceptibility to landslide failure of any particular geologic unit.

6. The slope map was then superimposed on the combined geologic map and landslide inventory and systematically examined to determine the slope intervals with maximum landslide frequency for each map unit. In every landslide locality, an attempt was made to determine the original slope before the landslide moved. Those slope inter- 


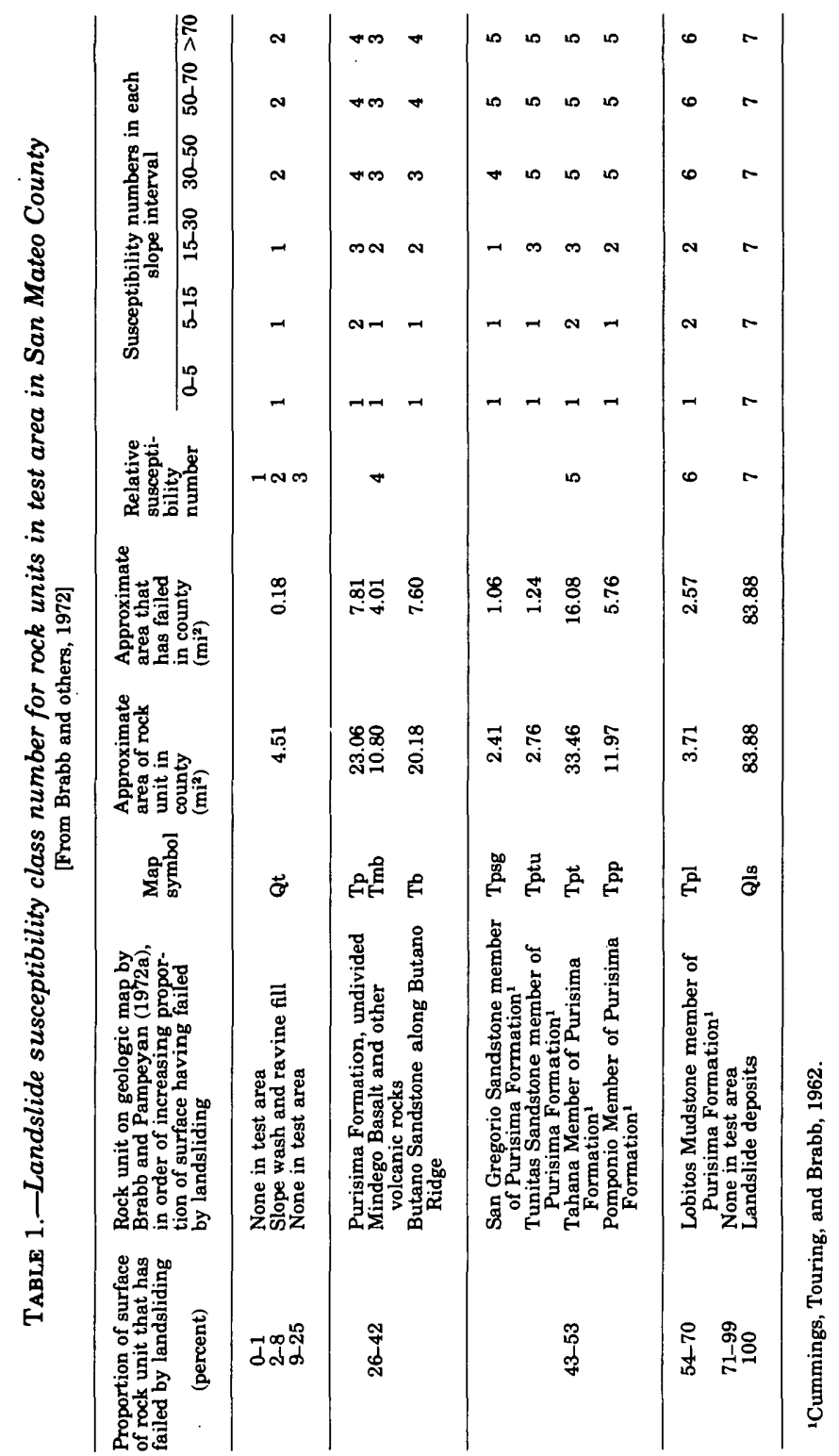


vals having the greatest number of landsides were then labeled with the highest class number. Slope intervals showing significantly fewer landslides were labeled with lower class numbers. Thus, a geologic unit having a maximum susceptibility of 3 would be labeled with that number on steep slopes, and with 2 or 1 on more gentle slopes with significantly fewer slides.

About 6 man-months of very tedious and meticulous labor were required to prepare the landslide susceptibility map of the entire San Mateo County area. The estimated cost was about $\$ 30,000$.

\section{COMPUTER METHOD}

The same geologic, landslide, and slope maps for the test area were analyzed using a computer, but the procedures varied from the manual method.

\section{GENERATING GRID-CELL MAPS}

We experimented with two grid-cell sizes, 500 feet $(152.4 \mathrm{~m})$ on a side and 250 feet $(76.2 \mathrm{~m})$ on a side at map scale. The larger grid was designed to correlate with the 500 -foot reliability figure mentioned by Brabb, Pampeyan, and Bonilla (1972), but the maps produced were too generalized and had such a blocky appearance in relation to the original maps prepared manually that we chose to use the smaller grid (see fig. 2). The 250 -foot ( 1.4 acre) cell size ensured that the smallest landslide and geologic units and most of the detailed slope units would be mapped; however, it may be beyond the limits of accuracy of the original data. Further experimentation with grid-cell sizes between 250 and 500 feet is warranted but was not possible during the present investigation. The 1.4-acre cell size produced 6,734 grid cells in the test area, which was within the computer processing limitation of 10,000 cells. (That limit has been increased to 40,000.)

To be used by the computer, map data must be in numerical (digital) form. The unit boundaries from the geologic map, landslide map, and slope map were first translated into $x, y$ coordinate locations using a CALMA digitizer and its related processing programs. The computer program CELSET (program A, p. 12) converted the coordinate data into grid-cell data, assigning the appropriate values of geology, landslide, and slope to the center of each grid cell. The gridcell maps were plotted and checked against the originals (pl. 1).

\section{ASSIGNING PRESLIDE SLOPES}

We attempted to program the computer to assign preslide slopes to the landslide units, because manually derived preslide slopes were 

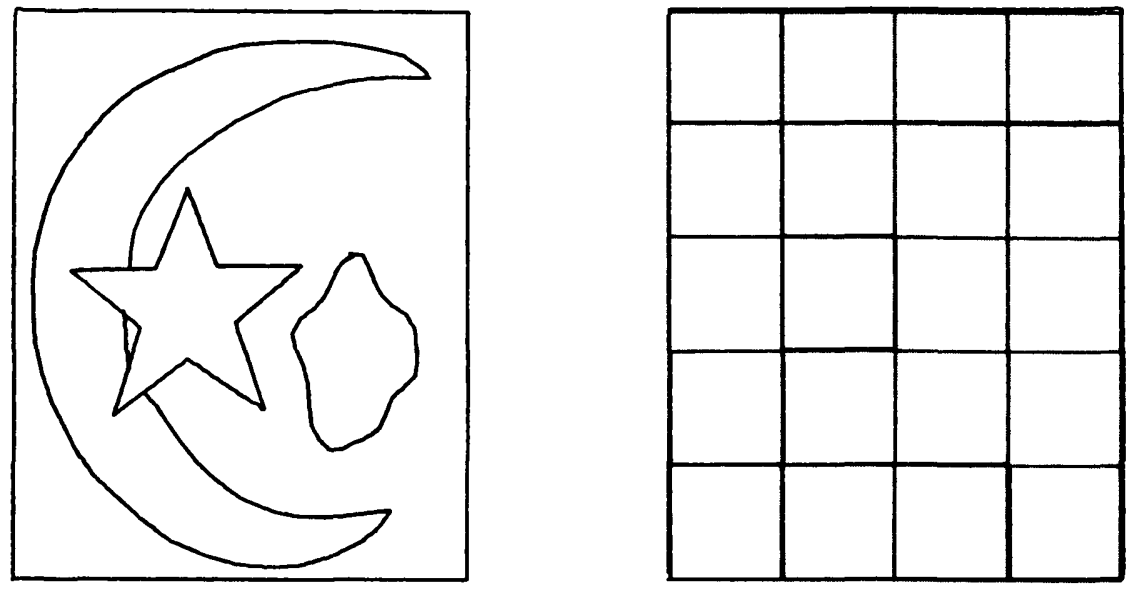

$\boldsymbol{A}$
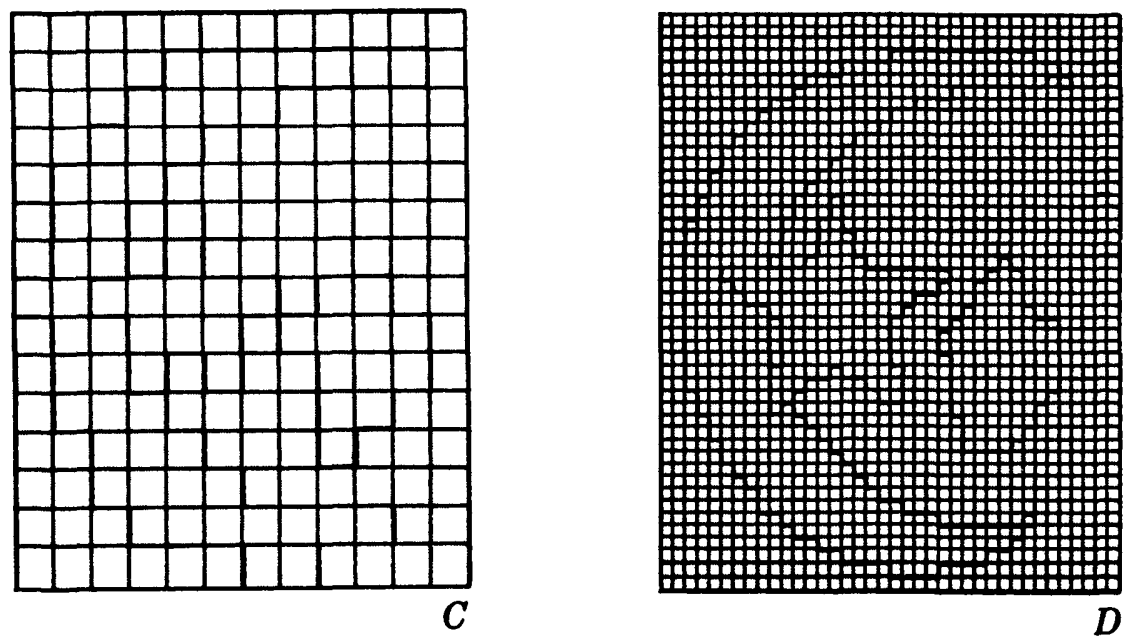

FigurE 2.-Conversion of map units to grid-cell format. $A$, Test map of geometric units formed by curves and angles other than $90^{\circ} . B$, Cells are 0.432 inch $(1.1 \mathrm{~cm})$ on a side and illustrate the shortcomings of the method when using too large a cell size. The irregular unit was not assigned a cell because no cell center was within its boundary, even though it covers 1.28 cells. The top point of the crescent was assigned a cell even though it occupies only 0.083 of the cell. The star became a square. $C$, Cells are 0.144 inch $(0.366 \mathrm{~cm})$ on a side and show greater detail than $B$ but are blocky in appearance. $D$, Cells are 0.048 inch $(0.122 \mathrm{~cm})$ on a side, which corresponds to 250 feet at $1: 62,500$ scale. 
used by Brabb, Pampeyan, and Bonilla (1972) to adjust the landslide susceptibility numbers. In general, landslides form steeper slopes in the headwall and toe areas and gentler slopes in the middle as compared to the original surface. The programs tried to determine preslide slope, but the results were unsatisfactory. We have tentatively decided that the geologist can do this part of the operation mre effectively than the computer. Accordingly, we used the matrix developed by Brabb, Pampeyan, and Bonilla (1972) in table 1 to adjust the landslide susceptibility numbers for each slope interval.

\section{ASSIGNING LANDSLIDE SUSCEPTIBILITY NUMBERS}

A computer program was written and tested for listing the geologic units with the proportion of their outcrop areas that had failed by landsliding in each slope interval. This subroutine CHARTX (program B, p. 14) (1) totaled the number of grid cells of each geologic unit in each slope interval, (2) totaled the number of grid cells of each geologic unit in each slope interval that had failed by landsliding, (3) computed the percentage of failure, (4) assigned the landslide susceptibility number on the basis of the percent-failure category, and (5) printed a chart of the above totals, percents, and landslide susceptibility categories assigned.

A map produced from these data would be representative of the test area but not of the county as a whole. To compare the manually produced map and the one produced by a computer, we gave the computer the landslide susceptibility numbers for the entire county used by Brabb, Pampeyan, and Bonilla (1972) as input data in the form of a $9 \times 6$ matrix. The computer program COMPOS (program B) then (1) located the geologic unit and slope category for each grid cell, (2) assigned each cell the landslide susceptibility number for that geologic unit and slope interval as found in the matrix, and (3) punched cards containing the landslide susceptibility numbers. The resulting grid-cell landslide susceptibility map is shown on plate 1 along with the manually prepared map.

\section{PLOTTING THE DATA}

In order to check the digitized input data, the landslide, geologic, and slope grid-cell maps were plotted. Program PLTCEL (program C, p. 19) (1) derived regions of common value by eliminating the boundaries between adjacent cells of equal value, (2) labeled the regions, 
and (3) punched output cards for use on plotter. The plotting program is versatile in that any map may be plotted within the boundary dimensions of the plotter $(29$ inches $(73.66 \mathrm{~cm})$ in one direction and 110 feet $(33.528 \mathrm{~m})$ in the other). We plotted an unlabeled 1:62,500 map for comparison with the manually compiled maps (pl. 1), and a larger, labeled map for readability and ease of checking map labels (fig. 3).

\section{COLOR OUTPUT}

The landslide susceptibility data were converted into three magnetic tape files for use on an image recorder. This unit reads the magnetic tape and exposes color film with blue, green, and red filters. Each tape file defines the amount of light needed to pass through the corresponding filter so that a unique color results for each code (pl. 1). The tape can be used with several film types: polaroid for quick-look, color negative, or color positive. Each tape file may also be exposed on separate pieces of color film in order to give the blue, green, and red separates needed in some printing processes. The program CAT2DICO that converted the grid-cell format into the image recorder format was developed by Robert E. Slye of Ames Research Center and is currently in use there.

\section{COST ANALYSIS}

The cost of producing the computerized landslide susceptibility map with a 250 -foot grid is $\$ 500$ to $\$ 800$ for a test area of approximately $15 \mathrm{mi}^{2}\left(39 \mathrm{~km}^{2}\right)$. The figures include digitizer, computer, labor, and overhead expenses.

TABLE 2.-Time and cost of producing computerized map

\begin{tabular}{|c|c|c|c|c|c|c|}
\hline County & $\underset{\left(\mathrm{mi}^{2}\right)}{\operatorname{Lan}}$ & $\underset{\left(\mathrm{km}^{2}\right)}{\operatorname{area}}$ & $\underset{\text { cost }}{\text { Minimum }}$ & $\underset{\text { (months) }}{\text { Time }}$ & $\underset{\text { cost }}{\text { Maximum }}$ & $\begin{array}{c}\text { Time } \\
\text { (months) }\end{array}$ \\
\hline $\begin{array}{l}\text { Alameda } \\
\text { Contra Costa } \\
\text { Marin } \\
\text { Napa } \\
\text { San Mateo } \\
\text { Santa Clara } \\
\text { Santa Cruz } \\
\text { Solano } \\
\text { Sonoma }\end{array}$ & $\begin{array}{r}733 \\
734 \\
520 \\
758 \\
454 \\
1,302 \\
439 \\
827 \\
1,579\end{array}$ & $\begin{array}{l}1,898 \\
1,901 \\
1,347 \\
1,963 \\
1,176 \\
3,372 \\
1,137 \\
2,142 \\
4,090\end{array}$ & $\begin{array}{r}\$ 24,500 \\
24,500 \\
17,500 \\
25,500 \\
15,500 \\
43,500 \\
15,000 \\
27,500 \\
52,500\end{array}$ & $\begin{array}{r}6 \\
6 \\
4 \\
6 \\
4 \\
10 \\
4 \\
6 \\
11\end{array}$ & $\begin{array}{r}\$ 39,200 \\
39,200 \\
28,000 \\
40,800 \\
24,800 \\
69,600 \\
24,000 \\
44,000 \\
84,000\end{array}$ & $\begin{array}{r}10 \\
10 \\
6 \\
10 \\
6 \\
15 \\
6 \\
10 \\
18\end{array}$ \\
\hline Total & & -..-. & $\overline{\$ 246,000}$ & $\overline{4.75 \mathrm{yr}}$ & $\overline{\$ 393,600}$ & $7.5 \mathrm{yr}$ \\
\hline
\end{tabular}


The estimated amount and times, shown in table 2, apply to nine counties in the San Francisco Bay region and are not meant to be universally valid. They indicate a reasonable range of expected values and assume availability of adequate geologic, landslide, and slope maps.

The wide range of estimated cost is due to uncertainties in the cost of digitizing slope maps and to uncertainties in predicting problems over large areas. The first county to use the computer system should expect the cost to be relatively high on the scale. As experience is gained, the cost and time should be reduced, except in counties where differing rock types require additional factor analysis.

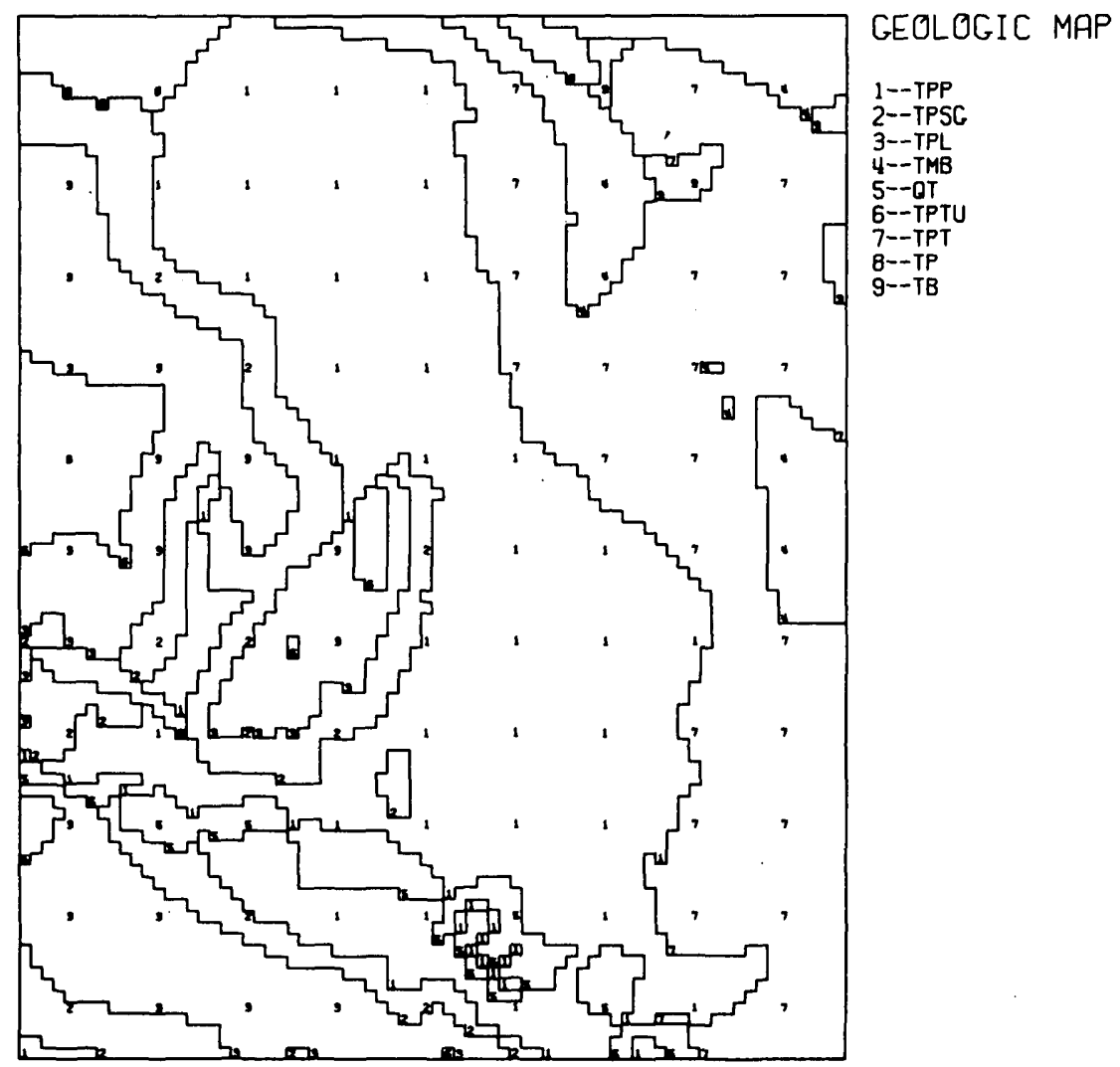

Figure 3.-Labeled geologic map of test area drawn by plotter. 


\section{CONCLUSIONS}

The ability to produce a computerized landslide susceptibility map has been demonstrated. Computerized maps can be generated in approximately the same time as and at less cost than a comparable map compiled manually, and with the following benefits: computer compilation (1) frees the scientist from the drudgery of meticulous labor, allowing more time to concentrate on investigating other factors that relate to landslide susceptibility, (2) eliminates errors in human calculation, assuming the input data and programs have been thoroughly checked before being processed, and (3) creates a data bank for use in future mapping in the same area when additional factors related to landsliding are discovered.

On the other hand, the computer process is not automatic. Considerable judgment is still required from the geologist and the programmer in preparing the map. More testing of larger areas and testing of different geologic terranes are required before this method can be considered reliable, but the results so far are highly encouraging.

\section{REFERENCES CITED}

Brabb, E. E., and Pampeyan, E.H., compilers, 1972a, Preliminary geologic map of San Mateo County, California: U.S. Geol. Survey Misc. Field Studies Map MF-328, scale 1:62,500.

1972b, Preliminary map of landslide deposits in San Mateo County, Caifornia: U.S. Geol. Survey Misc. Field Studies Map MF-344, scale 1:62,500.

Brabb, E. E., Pampeyan, E. H., and Bonilla, M. G., 1972, Landslide susceptibility in San Mateo County, California: U.S. Geol. Survey Misc. Field Studies Map MF360 , scale $1: 62,500$.

Cummings, J. C., Touring, C. M., and Brabb, E. E., 1962, Geology of the northern Santa Cruz Mountains, California: California Div. Mines and Geology Bull. 181, p. 179 220.

Taylor, F. A., and Brabb, E. E., 1972, Maps showing distribution and cost by counties of structurally damaging landslides in the San Francisco Bay region, California, winter of 1968-69: U.S. Geol. Survey Misc. Field Studies Map MF-327, scale $1: 500,000$ and $1: 1,000,000$. 


\section{COMPUTER PROGRAMS}




\section{PROGRAM A. MAP CONVERSION TO GRID-CELL ROUTINES}

Program CELSET and its two related subroutines MASKP and PLYTST are designed to accept $(x, y)$ coordinate data and related numeric codes that represent map unit boundaries. The output is a matrix of cells to which the codes have been assigned. The program listings below contain many comments to help the reader understand the conversion method.

The programs listed here were created for use on the CDC 7600 computer at the Lawrence Radiation Laboratory in Berkeley, Calif. Some of the code would have to be modified before use on other computer systems. We have tried to indicate where this would be necessary.

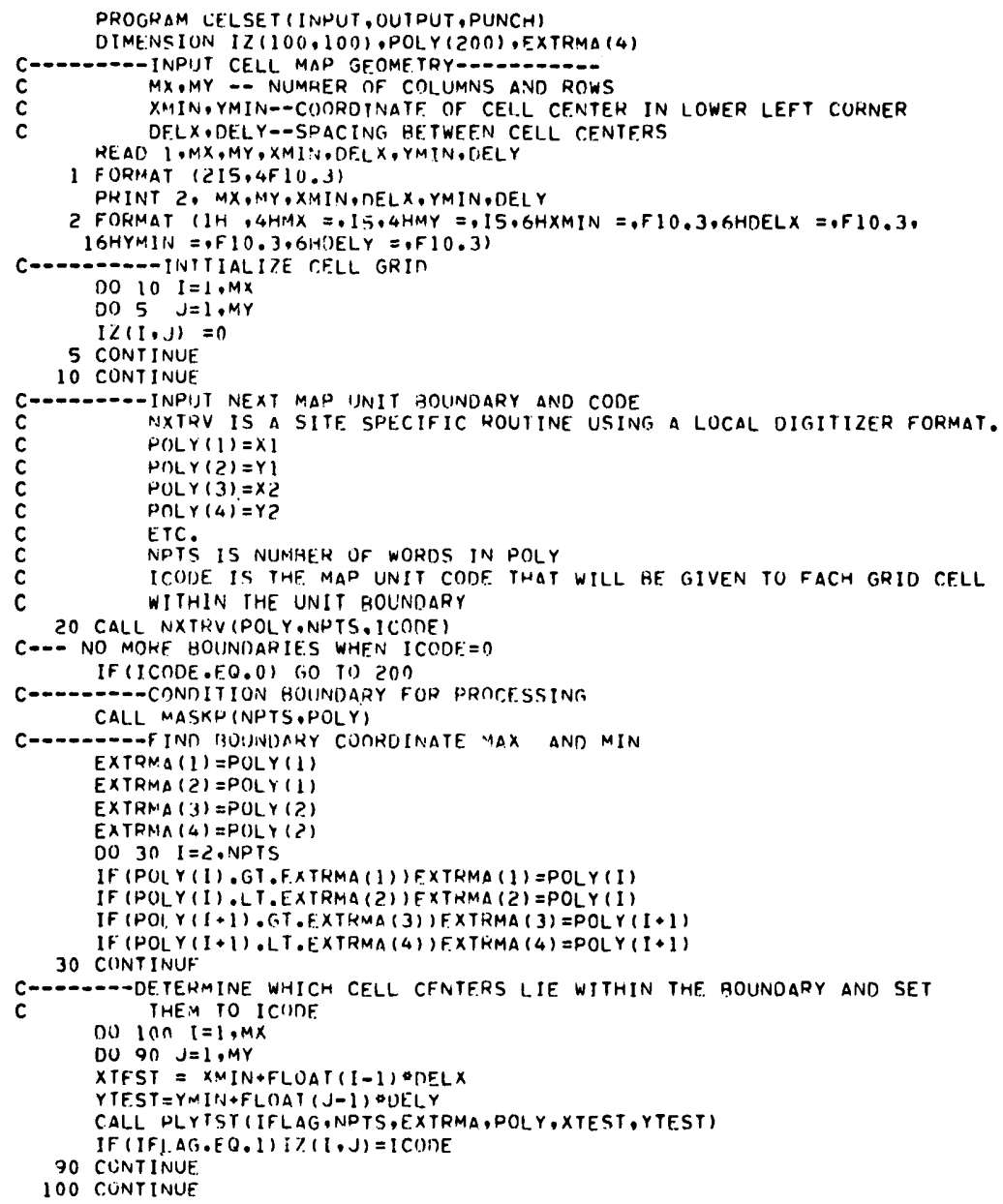




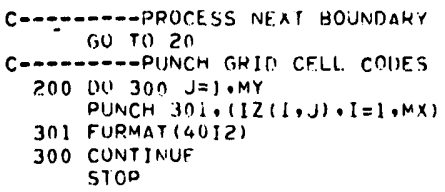

END

SUBROUTINE MASKP (NPTS,POLY)

PURPIISE--

CONDITIONS THE RFAL VALUES CONTAINEO IN THE ARRAY POLY

FOR LATER PRUCFSSING

COMPUTER DEPENOENT CONE

DIMENSION FOLY (1)

DO $10 I=1$, NPTS.?

POLY(I) = ANO (POLY(I), 777777777777777777748$)$

10 CUNTINUE

RETURN

END

SUBROUTINE PLYISTIIFLAG,NPTS, EXTRMA,POLY,XTEST,YTEST)

PIIRPOSE --

IO RETERMINE IF THE MID-POINT OF A CELL IS INSIDE OR

OUTSIDE OF A GIVFN MAP UNIT BOUNDARY. MF: IHUO--

IN GENERAL IT CAN HE DETERMINED IF A POINT LIES INSIDE

OH OUTSIOUE A CLOSED SOUNDARY IF A RAY FROM THE POINT IN

WUESTION ENCOUNTFRS AN ONO OR EVEN NUMBER OF INTERSECTIONS.

THE SUBROUTINE FIRST CHECKS IF THE TEST POINT LIES OUT OF

THE RANGE OF THE DATA ITSELF. IF IT DOES. THFN THE TEST POINT

URVIOUSLY CANNOT AE INSIDE. THE BOUNDARY. IF THE TEST POINT

IS FOUND TO LIE WITHIN THE RANGE OF THE DATA. MORE TESTS ARE MADE. THE GOUNUARY PUINTS ARE. TAKEN IN PAIRS. THE TEST POINT IS COMPARE') TO THE TWO BOUNIARY POINTS TO SEE IF ITS ARSCISSA IS CONTAINED IN THE NOMAIN OF THE GOUNDARY TEST SEGMENT. IF IT IS OUTSIDE THE NOMAIN. NO FURTHER TESTS ARE MAOE AND THE NEXT GOUINDAKY DOINT IS IJSED FOR THE NEW LINE SEGMENT. OTHERWISE THE INTERSECTION OF A VERTICAL RAY AND THE LINE IS CALCULATED. THE Y VALUE OF THIS POINT IS COMPARED WITH THAT OF THE TEST POINT. IF THE $Y$ VALUE OF THE INTERSECTION IS GREATER THAN THAT OF THE IFST PUINT THEN A COUNTER IS INCREMENTED. TO INDICATE THAT

A VALIO INTERSECTION HAS BEEN MADE. OTHERWISE. THE INTERSECTION IS NUT COUNTED. AFTEH ALL LINE SEGMENTS HAVE HEEN COMPARED $\triangle$ AFAINST THE TF.ST POINT, INCLUUING; THE LINE SFGMENT FROM THE N-TH WIINT (O) THE. FIPST. THE CUUNT IS EVALUATEN. IF THE NUMBER OF INTERSECTIONS IS DOD THE POINT IS INSIDE THE BOUNUARY AND IFLAG IS ASSICINED THE VALUE. OF 1 . IF THE NUMBER DF INTERSECTIONS IS FVEN. THE PUINT LIES OIITSIDE THE BOUNDARY AND IFLAG $=0$.

INPUT HAHAMETERS--

NPS-- THE NIMMER OF DATA POINTS THAT OEFINE THF. GOUNDARY

EXTKMA-- A LINFAL FOLIR ELEMENT ARRAY THAT CONTAINS THE MAXIMA ANI MINIMA OF THE $X$ AND Y DATA THAT DEFINES THF GOINDATY. EXTRMA (1) $=X M A X$, EXTRMA $(2)=X M I N$ FXTRMA $(3)=$ YMAX, EXTRMA $(4)=Y M I N$,

HOLY-- THE ARRAY WHICH HOLDS THE ACTUAL $X$ AND $Y$ VALUES OF THE DATA POINTS. NOTE THAT THE DIMENSION IS ONLY I, INDICATING A VARIAHLE NUMRË OF ELFMENTS WILL RE IISED EACH TIME THE. SURRIUUTINE IS USEE.

XIEST-- THE X COORDINATE OF THE TEST POINT.

YTEST-- THF Y CODROINATE OF THE TEST POINT. OUTPUT HARAMFIER--

IFLAGi-- IFLAG IS RETURNED TO INUICATE IF THE POINT IS INSIDE OR UUTSIDE THE RUUNDARY. A VALUE OF I INDICATES THAT THE POINT IS INSIDE, O INNICATES THAT THE POINT IS OUTSIDE

IFLAG $=0$

INSECT $=0$

$X P=X T E S T$

$Y P=Y T E S T$ 


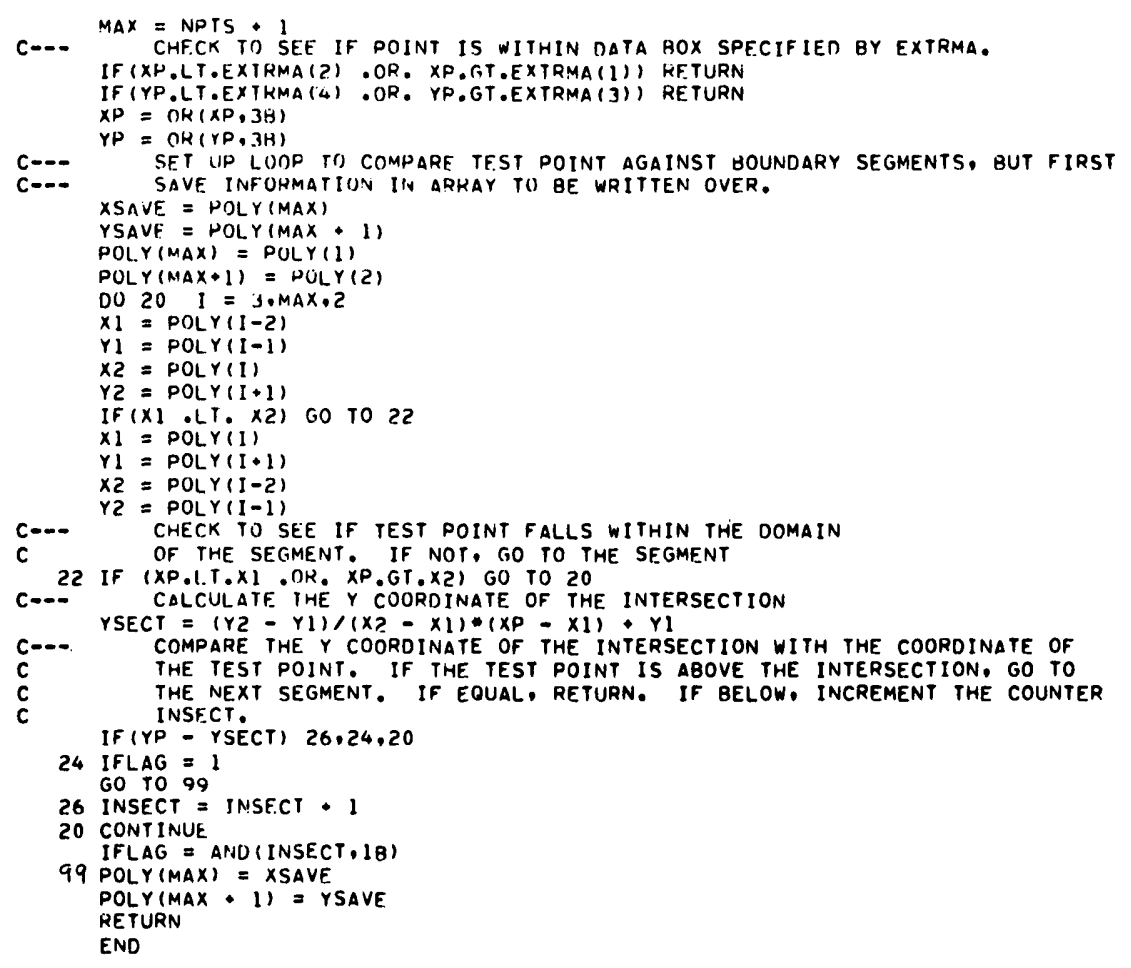

\section{PROGRAM B. LANDSLIDE SUSCEPTIBILITY CATEGORY ASSIGNMENT ROUTINES}

Program COMPOS uses slope, landslide, and geologic grid-cell data as input. It combines the data to produce landslide susceptibility categories as output in punched card form. The DATA statement contains the matrix data mentioned in the text and would be deleted or at least modified for future jobs.

Subroutine CHARTX produces a tabular output of the assignments to landslide susceptibility categories and area totals for each geologic type and slope category. The table at the end of CHARTX is an example. The data were used only to test the program. We checked the totals using a planimeter, and in each case the category assignment agreed with the computer.

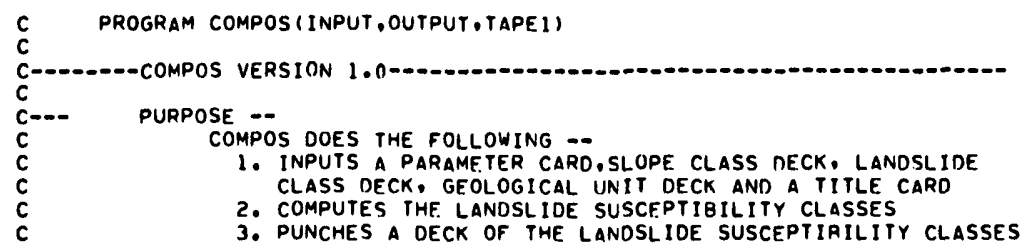




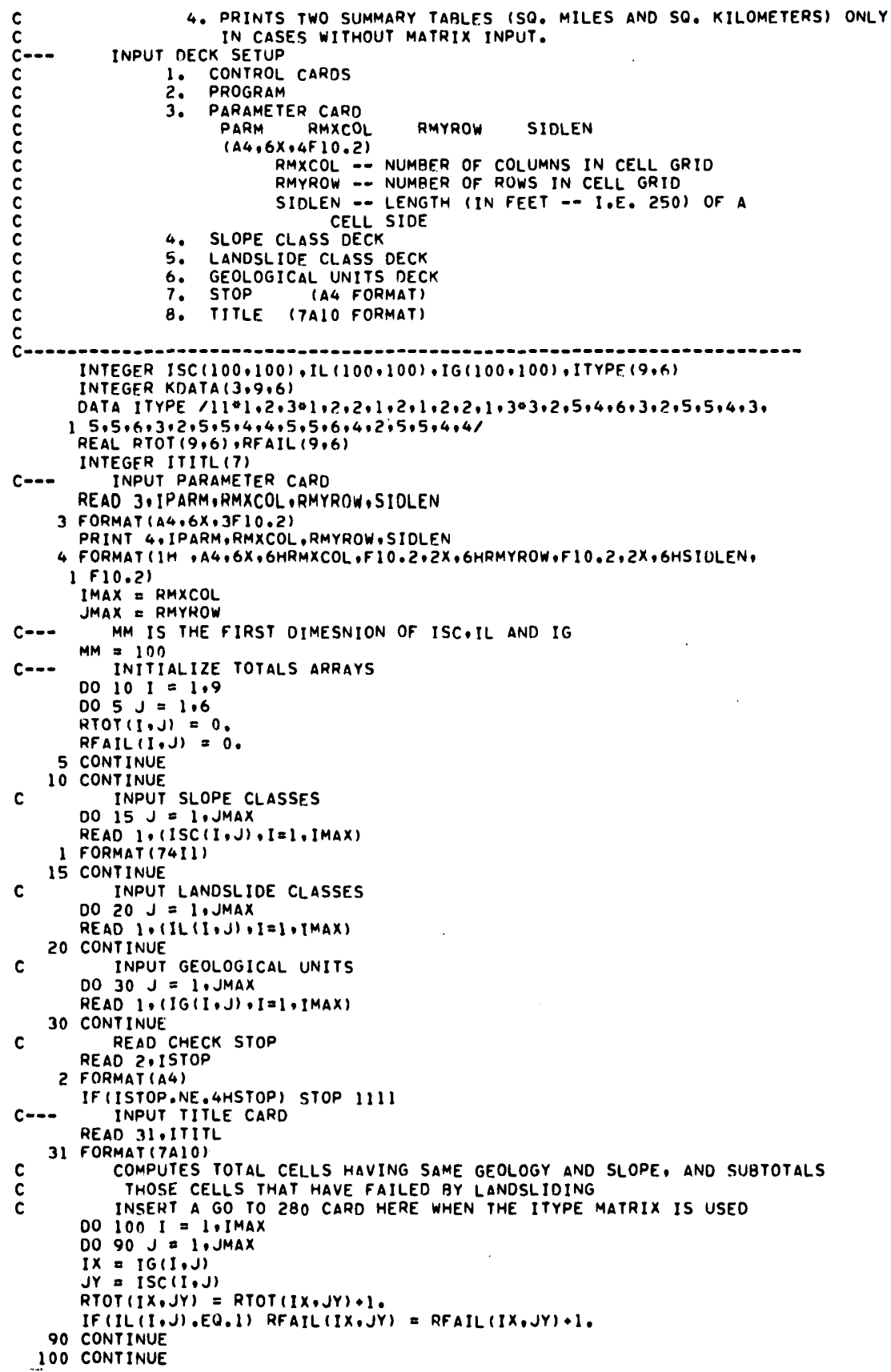


100 CONTINUE COMPUTE LANDSLIDE SUSCEPTIBILITY CATEGORIES FOR CELLS DO $200 \mathrm{I}=1.9$

DO $190 \mathrm{~J}=1,6$

IF (RTOTII,J) -EO,0.0) GO TO 190

PRCNT = RFAIL (I,J)/RTOT (I,J) IF (PRCNT.GT.0.01) GO TO 110 $I T Y P E(I, J)=1$ GO TO 190

110 IF (PRCNT.GT.0.08) GO TO 120 $I T Y P E(I, J)=2$ GO TO 190

120 IF (PRCNT.GT.0.25) GO TO 130 $\operatorname{ITYPE}(I, J)=3$ GO TO 190

130 IF (PRCNT.GT.0.42) GO TO 140

$\operatorname{ITYPE}(I, J)=4$ GO TO 190

140 IF (PRCNT.GT.0.53) GO TO 150 $I \operatorname{TYPE}(I, J)=5$ GO TO 190

150 IF(PRCNT.GT.0.70) GO TO 160 $I T Y P E(l \cdot J)=6$ GO TO 190

$160 \operatorname{ITYPE}(I, J)=$ ?

190 CONTINUE

200 CONTINUE

280 DO $300 \mathrm{I}=1$, IMAX

DO $290 \mathrm{~J}=1$, JMAX

$I X=I G(I, J)$

$I Y=I S C(I, J)$

$\operatorname{ISC}(I, J)=\operatorname{ITYPE}(I X, I Y)$

IF (IL (I,J),EQ.1) ISC (I,J) = ?

290 CONTINUE

300 CONTINUE

c

PUNCH FINAL RESULTS

DO $400 \mathrm{~J}=1$. JMAX

WRITE $(1,1) \quad([S C(I, J)]=$,1 , IMAX)

400 CONTINUE

C INSERT A GO TO 99 CARD HFRE WHEN THE ITYPE MATRIX IS USED DO 5 On $J=1,6$ DO $405 I=1.9$

$\operatorname{KDATA}(3, I, J)=I T Y P E(I, J)$

405 CONTINUE

DO $410 \quad I=1.9$

$\operatorname{KDATA}(1,1, J)=\operatorname{RTOT}(I, J)$

410 CONTINUE

DO $420 \quad I=1.9$

$\operatorname{KDATA}(2, I, J)=\operatorname{RFAIL}(I, J)$

420 CONTINUE

500 CONTINUE

CALL CHARTXIKDATA,SIOLEN,1,ITITL)

CALL CHARTX (KDATA SIDLEN, 2.ITITL)

99 CONTINUE

STOP

ENn

SURROUTINE CHARTX (KDATA,SIDLEN,KLOFLG,T)

$c$

C-..-CHARTX VERSION 1.1 APRIL 11975

C-D PURPOSE --

C CHARTX PRINTS THE SUMMARY TABLE

C-- INPUT PARAMETERS --

C KDATA - 3 DIM ARRAY CONTAINING TOTAL AREA.AREA FAIL, AND TYPE FOR EACH GEOLOGICAL TYPE AND SLOPE CLASS SIDLEN -- LENGTH IIN FEET -- I.E. 250) OF A CELL SIDE KLOFLG -- SQ. MILES OR SO. KILOMETERS FLAG

$=1$ PRINT TABLE IN SO. MILES

$=2$ PRINT TARLE IN SO. KILOMETERS

T -- tABLE TITLE (7AIO fORMAT)

OUTPUT PARAMETERS --

a TABLE IS PRINTED. NOTE THAT THE daTA AND FORMAT STATEMENTS ARE COMPUTER DEPENDENT 


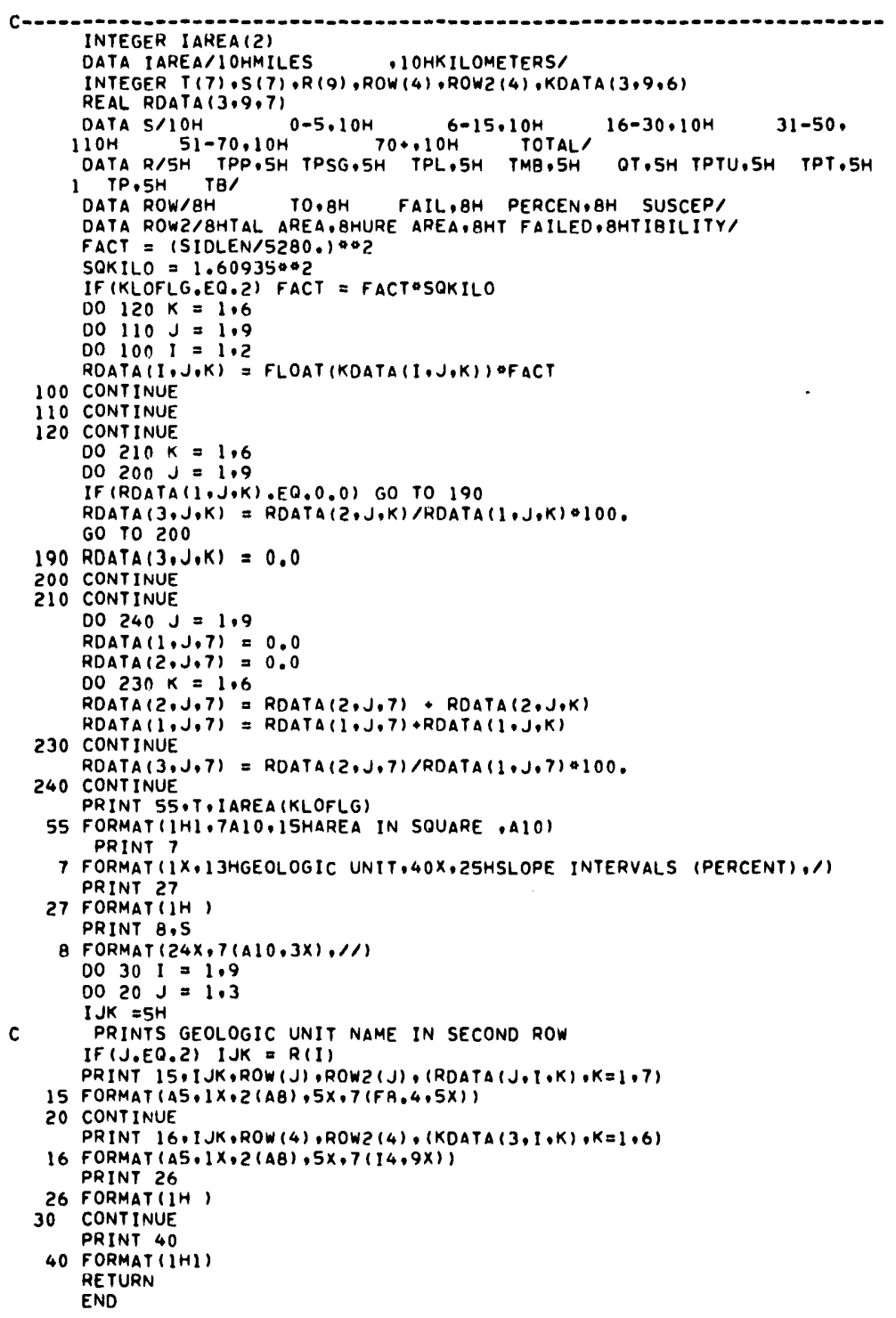




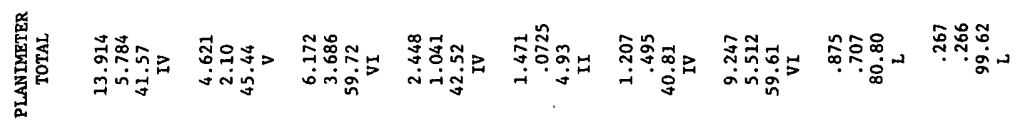

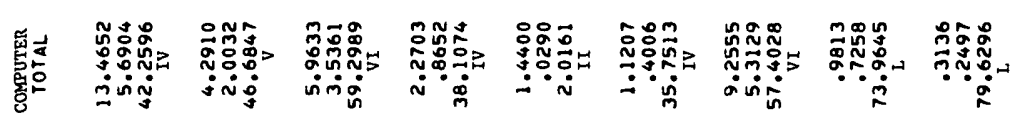

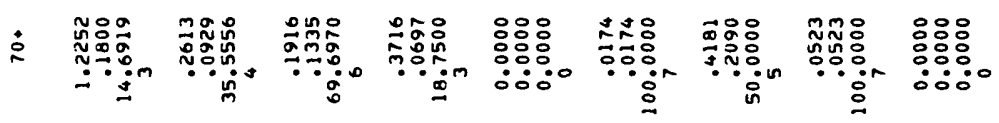

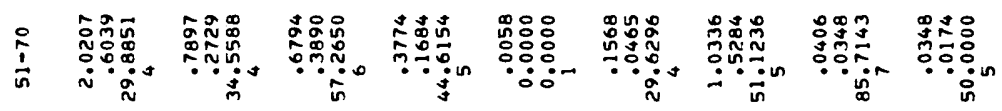

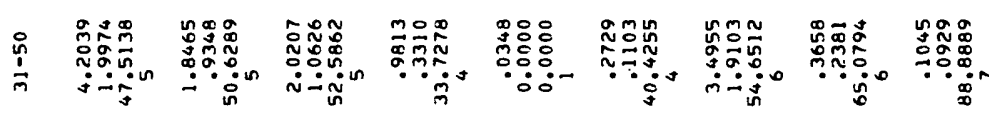

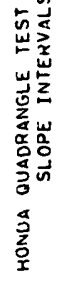

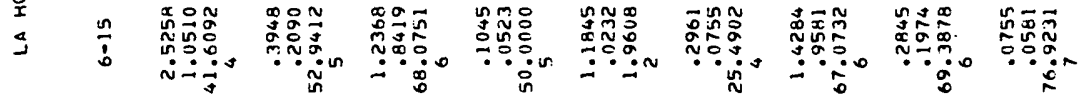

")

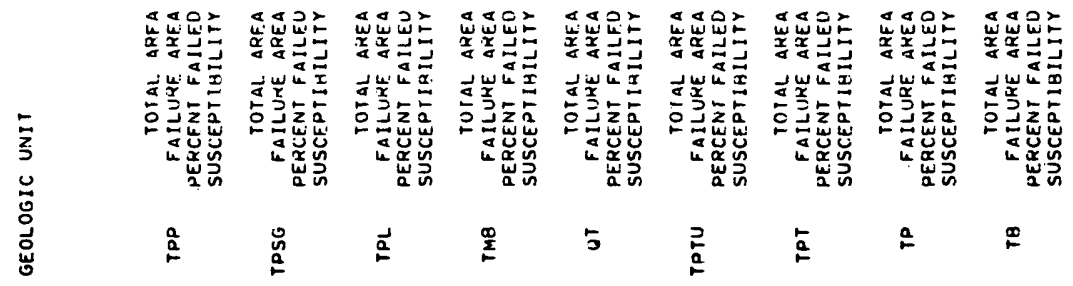




\section{PROGRAM C. PLOTTING ROUTINES}

Program PLTCEL and its related subroutines CELPLT, CFOLLW, CHKCEL, and DGBITR are utilized in conjunction with local installation Calcomp plotting routines (SYMBOL and PLOT) to produce a labeled plot like the one shown in figure 3 . Comments within the listings describe the method by which grid cell data are converted to common regions and plotted.

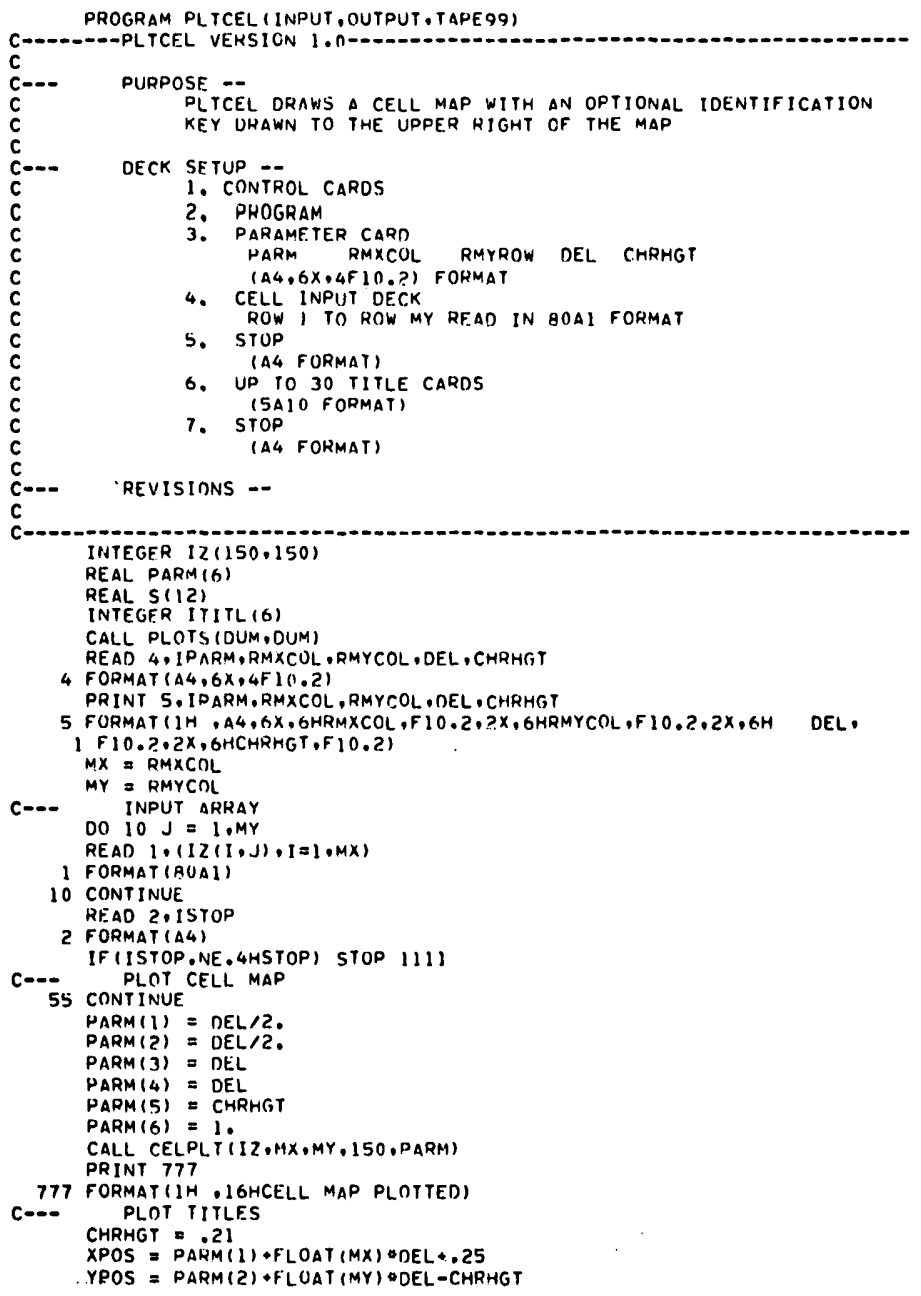




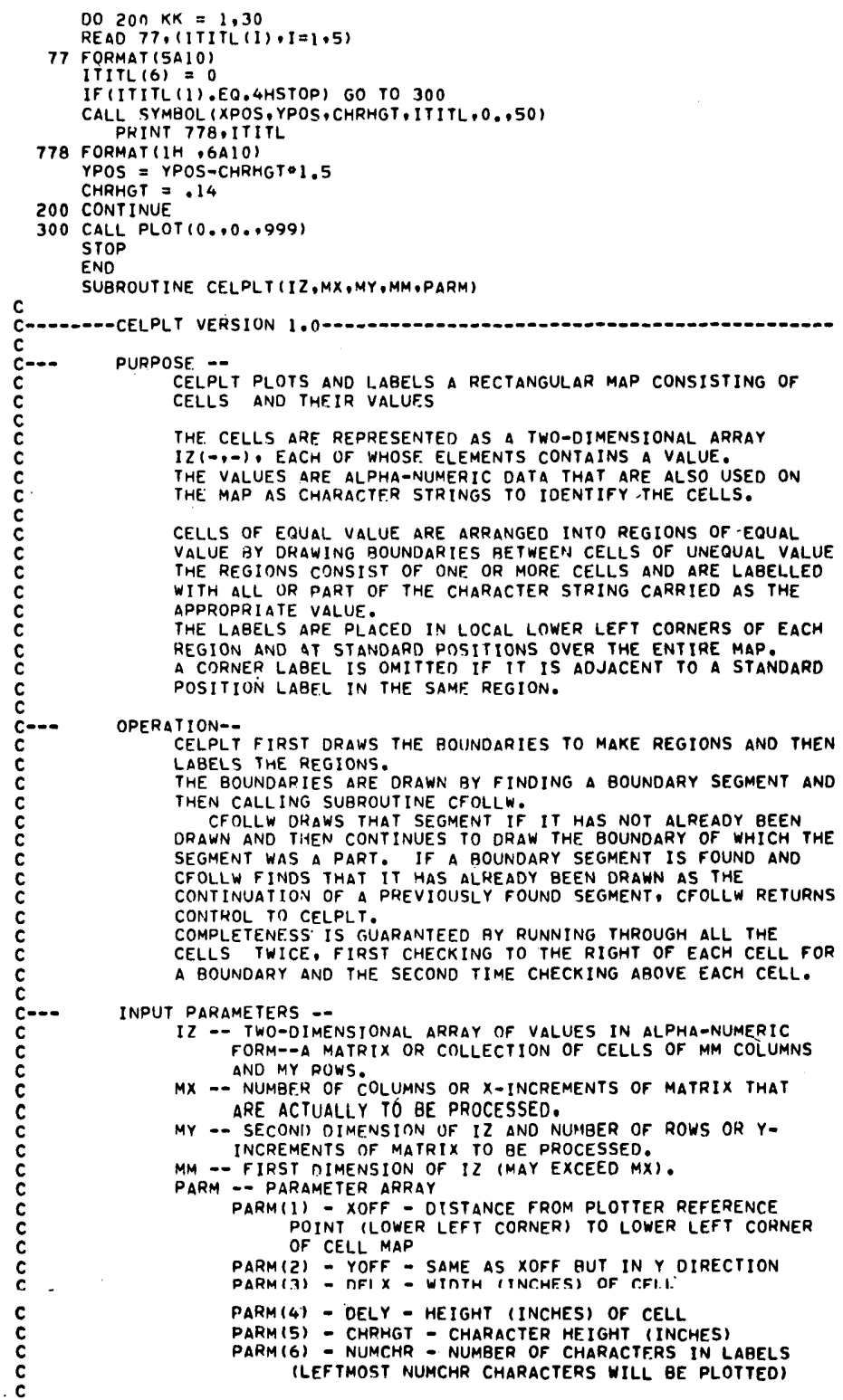




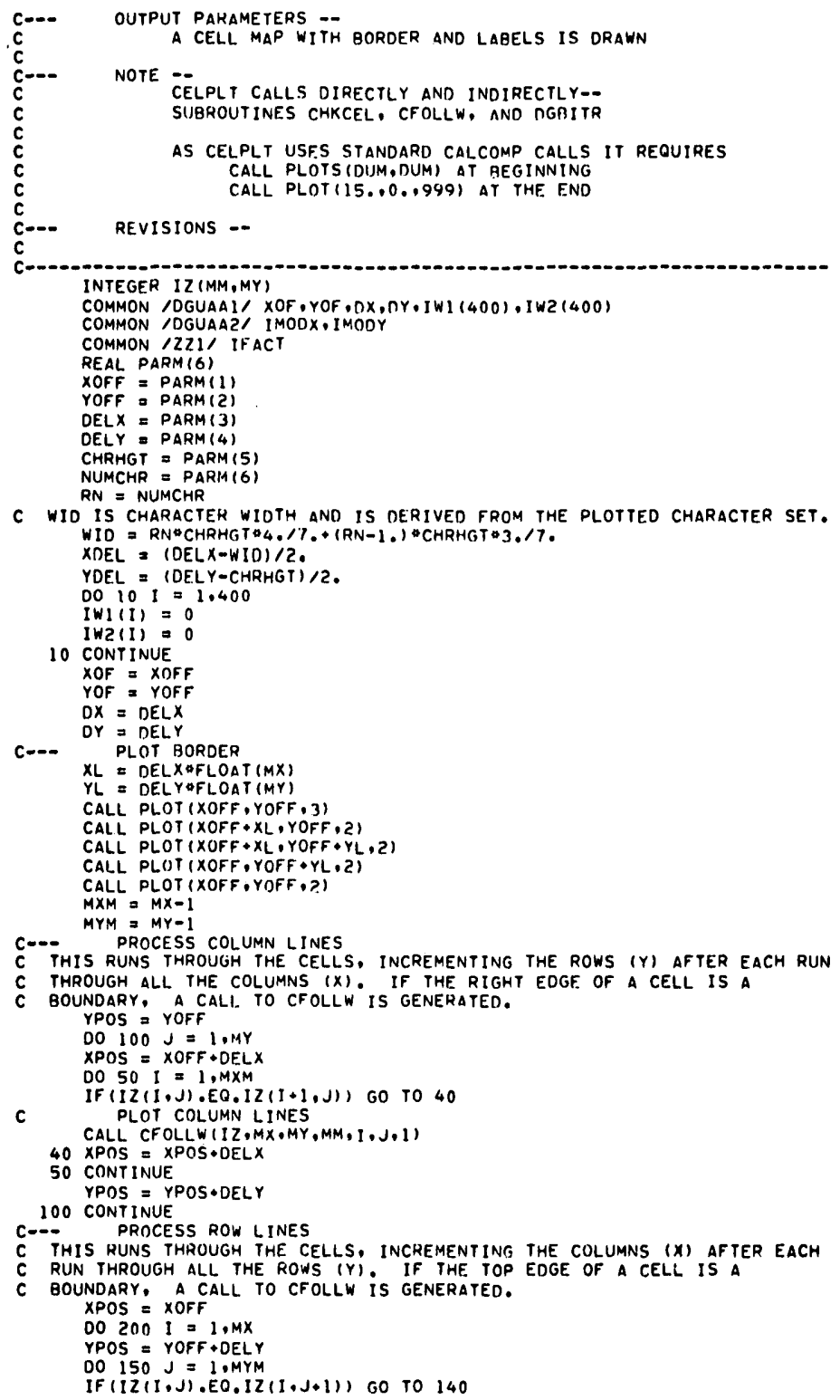


c PLOT ROW LINE

CALL CFOLLW(IZ,MX,MY,MM, I,J,2)

140 YPOS Y YPOS $+D E L Y$

150 CONTINUE

XPOS $=X P O S+O E L X$

200 CONTINUE

C PLOT TITLES

YPOS $=$ YOFF Y YDEL
IF $2 E R O$ HEIGHT LABELS -- DON"T BOTHER DRAWING LABELS

IF ICHRHGT.LE. 0.0$)$ RETURN

C THESE DEFINE STANDARD LABEL POSITIONS.

INTX $=4$

INTY $=4$

IDELX $=8$

IDELY $=8$

$00300 \mathrm{~J}=1$, MY

$X P O S=X O F F+X O E L$

IMOOX $=3$

IMOOY $=3$

CALL CHKCEL (IZ,MX,MY,MM,1,J.XPOS,YPOS, CHRHGT, NUMCHR)

$X P O S=X P O S+D E L X$

c BASIC ALGORITHM OF 250 DO-LOOP--

If THE CELL IS A STANDARD LABEL POSITIION

THEN PLOT LABEL

ELSE IF THE CELL TO THE LEFT HAS A DIFFERENT VALUE

THEN CALL CHKCEL

GO TO NEXT CELL

DO $250 \mathrm{I}=2 . \mathrm{MX}$

ZTST $=I Z(1, J)$

$I M O D X=\operatorname{MOD}(I-I N T X, I D E L X)$

$I M O O Y=M O D(J-I N T Y, I D E L Y)$

IF (IIMOOX,EO.1).AND. (IMOOY,EO.11) GO TO 230

IF (IZ (I,J).EQ.IZ(I-I,J)) GO TO 240

C BOUNDARY SO CHECK

CALL CHKCEL (IZ,MX,MY,MM,I,J,XPOS,YPOS, CHRHGT, NUMCHR )

GO TO 240

230 CALL SYMBOL (XPOS, YPOS, CHRHGT, $1 Z 11, \mathrm{~J}), 0$, , NUMCHR)

240 XPOS $=$ XPOS $+D E L X$

250 CONTINUE

YPOS $=$ YPOS +DELY

300 CONTINUE

RETURN

END

c

SUBROUTINE CFOLLW(1Z,MX,MY,MM, II,JJ,ITYPE)

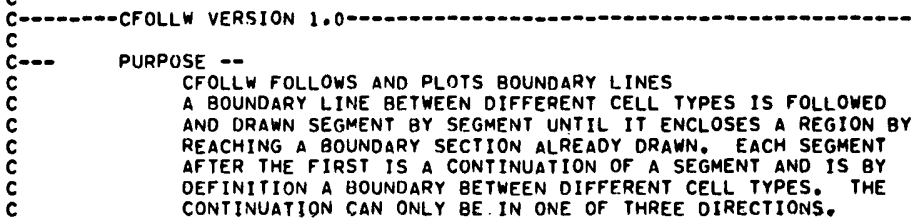

OPERATION--

THE CENTRAL ALGORITHM FINOS AN UNORAWN CONTINUATION OF THE CURRENT SEGMENT, IF ONE EXISTS.

THE ALGORITHM IS IFPLEMENTED IN FOUR VARIATIONS, WHICH

DEPEND ON THE FORM OF THE LAST PREVIOUS SEGMENT AND WHICH START AT LABELS 200, 300, 400, 500

THE FIRST SEGMENT OF. EACH SEQUENCE OF SEGMENTS IS GENERATED AS A SPECIAL CASE. PRECEOING LABEL 100, FROM A BOUNOARY FOUND IN THE CALLING ROUTINE AND SPECIFIED BY PARAMETERS II, JJ, ITYPE.

A RECORD OF WHICH BOUNDARY SEGMENTS HAVE BEEN DRAWN IS KEPT IN ARRAYS IWI $(-)$ AND IW2(-).

THE STATUS OF THE RIGHT HAND BOUNDARY OF EACH CELL \{I,J\} IS REPRESENTED BY A BIT IN ARRAY IWI (-). 


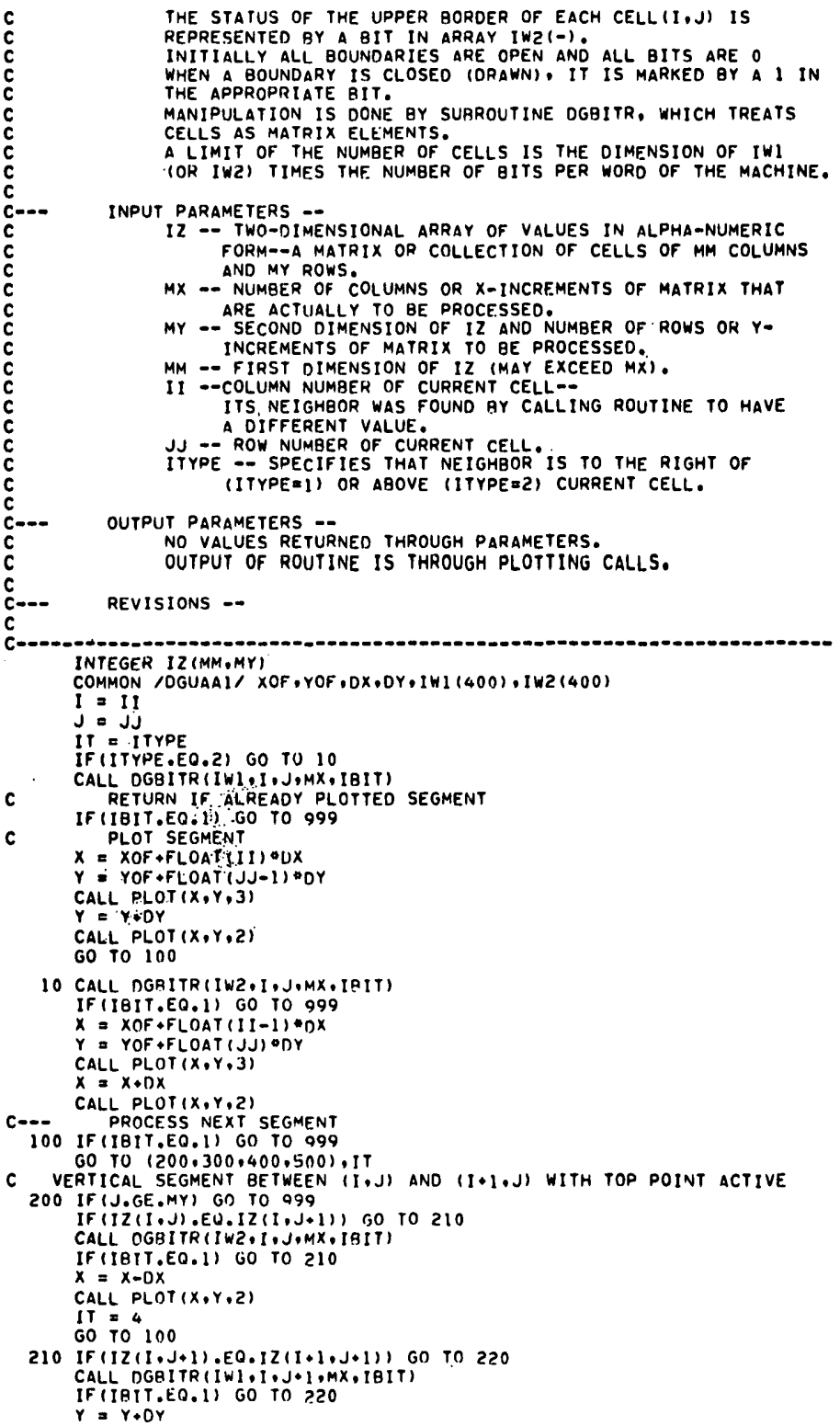




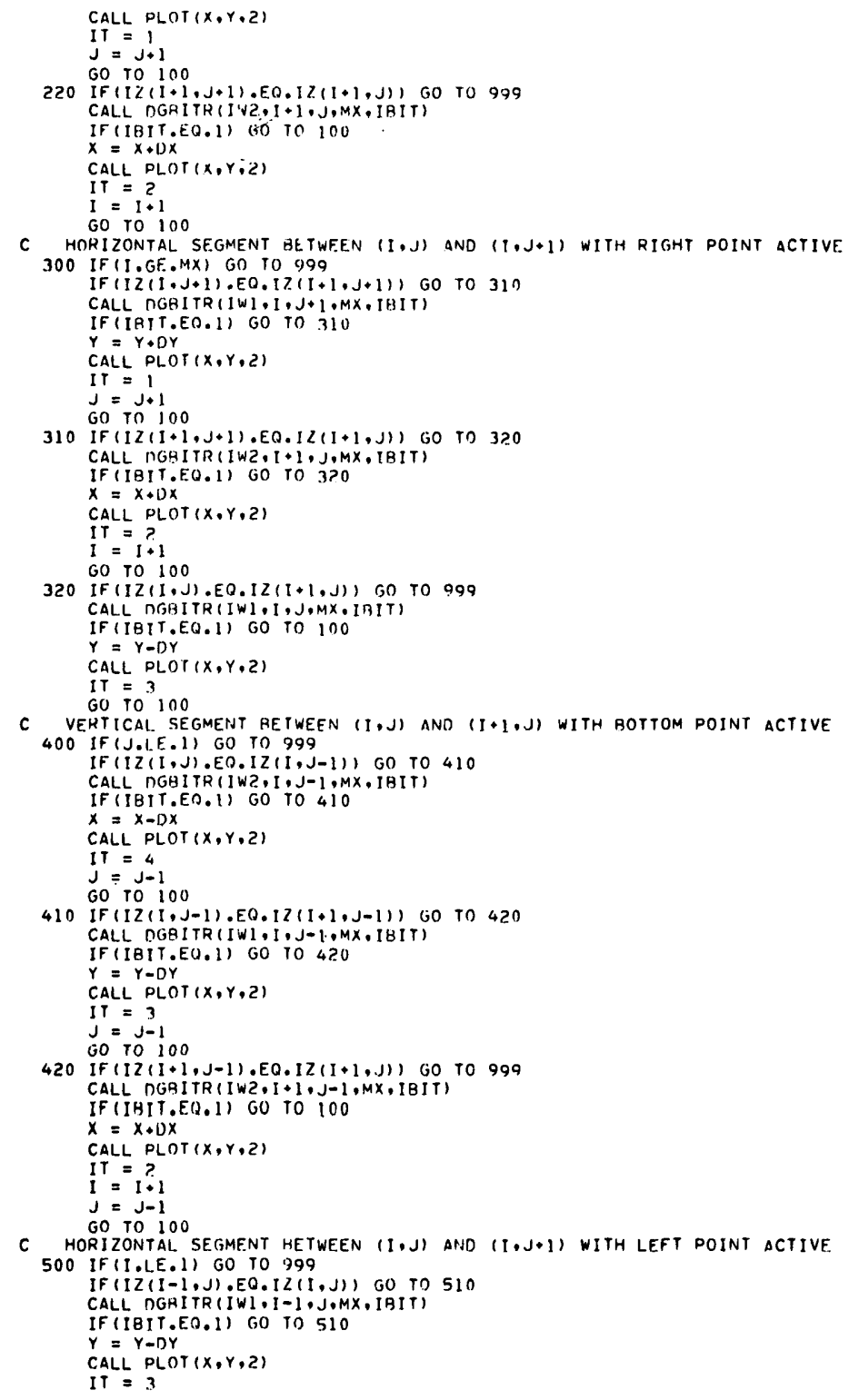


$I_{00}=10$

510 If $(12(1-1, J) \cdot E 0.12(1-1, J \cdot 1)$ iO TO 520

CALL DGAITRIIWL,I-1,J,MX, IBIT)

IF IIBIT.EQ.1) GO TO 520

$x=X-D x$

CALL PLOT $(X, Y, Z)$

IT $=4$

$1=1-1$

520 IF $(1 Z(I-1, J+1), E 0 \cdot 1211, J+1))$ GO TO 999

CALL DGBITRIIWI,I-1,J・I,Mx,IBIT)

IFIIBIT.EQ.1) GO TO 100

$r=Y \circ O Y$

CALL PLOT $(X, Y, Z)$

IT $=$ ?

$1=1-1$

$J=j+1$

60 To 100

Cag CONTINUE

RETURN

END

SUBROUTINE CHKCEL $112, M X, M Y, M M, I I, J J, X P O S, Y P O S, C H R H G T, N U M C H R$ I

C-D-CHKCEL VERSION $1,0-\cdots$

C-D. PUPPOSE -

CHKCEL DETERMINES WHETHEP A CELL IS A LOCAL LOWER LEFT CORNER OF A REGION AND, IF IT 1S, WHETHER IT IS ADJACENT

TO A STANOARD LABEL POSITION IN THE SAME REgION. IF IT

IS A CORNER ANO IS NOT AOJACENT TO A STANDARO LAREL, THFN

A LABEL IS PLOTTED.

A LOCAL LOWER LEFT CORNER CELL IS DEFINED BY--

1. A BOUNOARY SEGMENT OR MAP BORDER IMMEDIATELY TO THE LEFT OF THE CELL

2. A BOUNDARY SEGMENT OR MAP BORDER IMMENIATELY BELOW THE CELL.

3. A BOUNDARY SEGMENT OR MAP BORDER AT SOME DISTANCE

TO THE RIGMT OF THE CELL

4. THE BDUNDARY SEGMENTS BETWEen THE LOWER EDGe

SEGMENT AND THE RIGHT ROUNOARY SEGMENT ALL

haVe tHE. SAME $Y$ VALUE

OPERATION--

THE CALLING ROUTINF TRANSMITS A CELL(II,JJ) WHICH IS KNOWN TO HAVE A RUUNDARY TO ITS LEFT. CHKCEL EXAMINES THE CELLS GELOW AND TO THE. RIGHT TO SEE IF THE BOUNDARY TURNS

DOWNWARD IN VAL.JE BEFORE IT IURNS UPWARO OR REACHES

THE MAP BORDER.

INPUT PARAMETERS --

12 -- TWO-OIMENSIONAL ARRAY OF VALUES IN ALPHA-NUMERIC FORM--A MATRIX OR COLLECTION HF CELLS OF MM COLUMNS $\triangle N D$ MY ROWS.

MX -- NUMBER OF COLUMNS OR X-INCREMENTS OF MATRIX THAT ARE ACTUALLY TO BE PROCESSED.

MY - - SECUNO DIMENSION OF I2 AND NUMBER OF ROWS OR $Y$ INCREMENTS OF MATRIX TO AE PROCESSED.

$M M$-- FIRST OIMENSION OF IZ (MAY EXCEED MX).

II --COLIMMN NUMBEA OF CURRENT CELL-ITS NEIGHBOR WAS FOUND aY CALLING ROUTINE. TO HAVE A DIFFERENT VALUE.

JJ -- ROW NUMBER OF CIJRRENT CEILL.

XPOS -- POSITION OF LEFT haND EDGE OF LAGEL RELATIVE TO MAP ORIGIN.

YPOS -- POSITION OF BASE LINE OF LABEL RELATIVF. TO MAP ORIGIN.

CHRHGT - - CHARACTER HEIGHT (INCHES)

NUMCHR -. NUMBER OF CHARACTERS IN LABEL. 


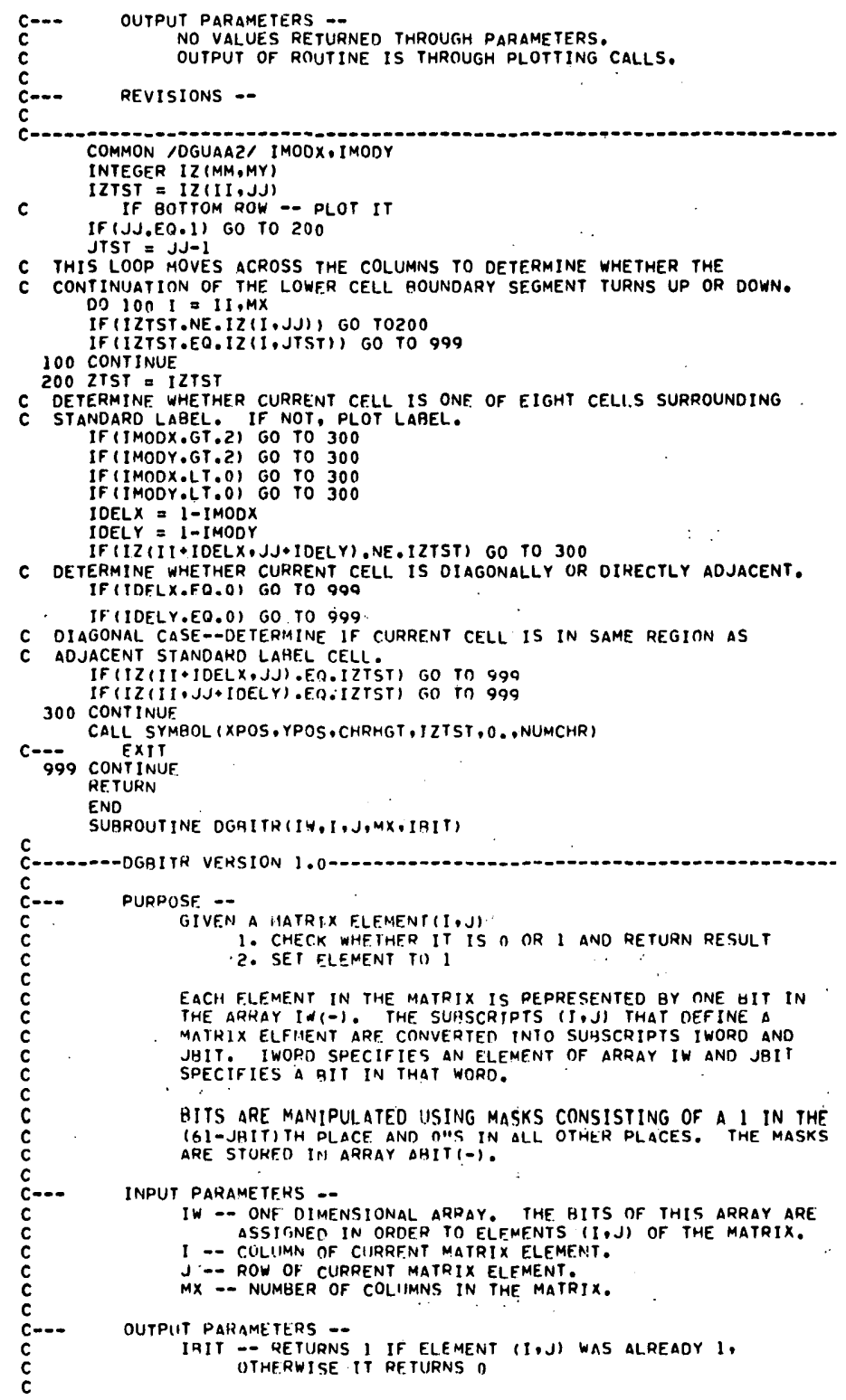




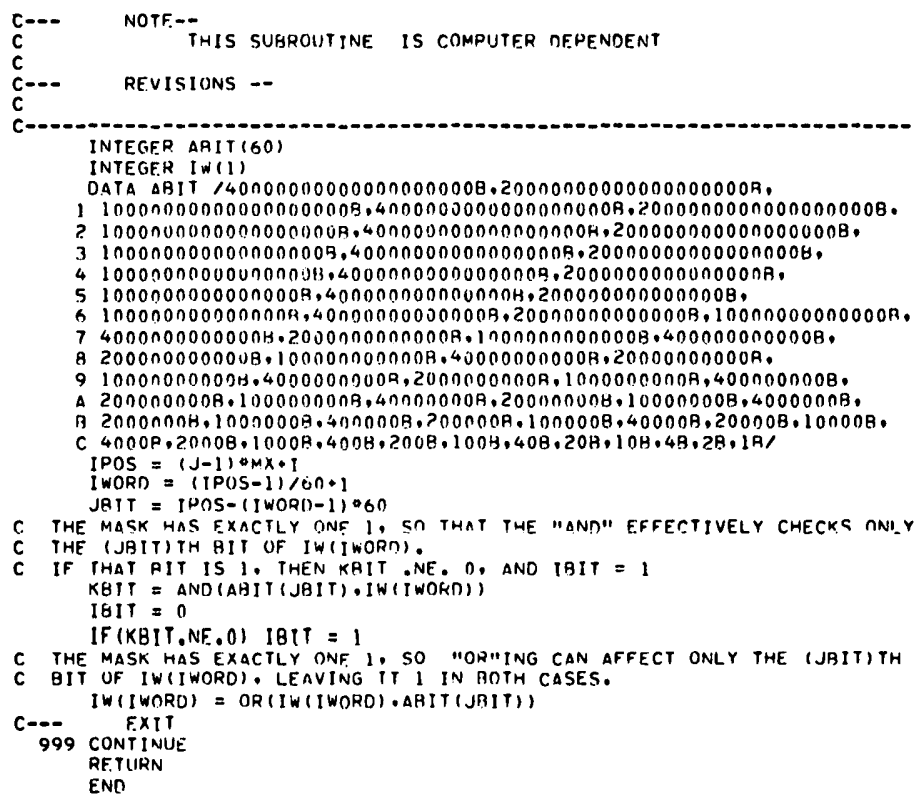

